\title{
Analysis of Acquisition Parameters That Caused Artifacts in Four-dimensional (4D) CT Images of Targets Undergoing Regular Motion
}

\author{
Heesoon Sheen*${ }^{\dagger}$, Youngyih $\operatorname{Han}^{\star}{ }^{\ddagger}$, Eunhyuk Shin ${ }^{\ddagger}$ \\ *Boi-Medical Engineering, Medical School Sungkyunkwan University, \\ ${ }^{\dagger}$ GE Healthcare Korea, ${ }^{\ddagger}$ Department of Radiation Oncology, Samsung Medical Center, Seoul, Korea
}

\begin{abstract}
The aim of this study was to clarify the impacts of acquisition parameters on artifacts in four-dimensional computed tomography (4D CT) images, such as the partial volume effect (PVE), partial projection effect (PPE), and mis-matching of initial motion phases between adjacent beds (MMimph) in cine mode scanning. A thoracic phantom and two cylindrical phantoms $(2 \mathrm{~cm}$ diameter and heights of $0.5 \mathrm{~cm}$ for No.1 and $10 \mathrm{~cm}$ for No.2) were scanned using $4 \mathrm{D}$ CT. For the thoracic phantom, acquisition was started automatically in the first scan with $5 \mathrm{sec}$ and $8 \mathrm{sec}$ of gantry rotation, thereby allowing a different phase at the initial projection of each bed. In the second scan, the initial projection at each bed was manually synchronized with the inhalation phase to minimize the MMimph. The third scan was intentionally un-synchronized with the inhalation phase. In the cylindrical phantom scan, one bed $(2 \mathrm{~cm})$ and three beds $(6 \mathrm{~cm})$ were used for 2 and 6 sec motion periods. Measured target volume to true volume ratios (MsTrueV) were computed. The relationships among MMimph, MsTrueV, and velocity were investigated. In the thoracic phantom, shorter gantry rotation provided more precise volume and was highly correlated with velocity when MMimph was minimal. MMimph reduced the correlation. For moving cylinder No. 1, MsTrueV was correlated with velocity, but the larger MMimph for $2 \mathrm{sec}$ of motion removed the correlation. The volume of No. 2 was similar to the static volume due to the small PVE, PPE, and MMimph. Smaller target velocity and faster gantry rotation resulted in a more accurate volume description. The MMimph was the main parameter weakening the correlation between MsTrueV and velocity. Without reducing the MMimph, controlling target velocity and gantry rotation will not guarantee accurate image presentation given current $4 \mathrm{D}$ CT technology.
\end{abstract}

Key Words: 4-dimensional computed tomography (4D CT), Partial volume effect (PVE), Partial projection effect (PPE), Mis-matching of initial motion phases between adjacent beds (MMimph)

\section{INTRODUCTION}

State-of-the art radiation therapies, such as intensity- modulated radiation therapy (IMRT), stereotactic radiotherapy, and particle therapy, require precise geometric knowledge of tumor volume. ${ }^{1)}$ However, organ motion due to breathing hinders the exact determination of target volume since it gives rise to serious representation errors in computed tomography (CT) im-

Submitted September, 23, 2013, Accepted December, 12, 2013 Corresponding Author: Youngyih Han, Department of Radiation Oncology, Samsung Medical Center, 81, Irwon-ro, Gangnam-gu, Seoul 135-710, Korea

Tel: 02)3410-2604, Fax: 02)3410-2610

E-mail: youngyih@skku.edu ages, thereby increasing uncertainty in treatment planning and delivery. ${ }^{2-4)}$ Currently, four-dimensional computed tomography (4D CT), which is time-resolved CT scanning, is widely used for mitigating motion artifacts in clinical practice, although it cannot eliminate all motion artifacts. Four-dimensional CT data still suffer from artifacts caused by the partial projection effect (PPE) and mis-matching of initial motion phases between adjacent beds (MMimph).

The parameters contributing to 4D CT image quality include the gantry rotation speed, interval between images, and scan duration in retrospect scanning. ${ }^{5-9)}$ Temporal resolution in cine images is associated with gantry rotation speed relative to subject motion. In cine scanning which is a retrospective $4 \mathrm{D} C \mathrm{CT}$ 
technique, cine interval time and duration are linked to the quality of images reconstructed from raw projection data through one gantry rotation. Prospective scans are theoretically less prone to cause motion artifacts in 4D CT images. However, they require a longer scan time when the patient's breathing is not regular, since they produce only one series of images for the predefined respiratory phase. Four-dimensional CT images acquired by retrospective scanning contain more evident artifacts while providing multiple series for different respiratory phases.

Several authors ${ }^{10,12-14)}$ have investigated artifacts in 4D CT images. Eike Rietzel et al. ${ }^{5)}$ explored the impact of target motion on the PPE, but detailed relationships among motion, projection parameters, and artifacts were not clearly described. Mori et al. ${ }^{12)}$ found that banding artifacts were partly caused by a mismatch among respiratory phases of an organ location at each of the couch positions. The volume representation on 4D CT images is affected by target speed, and this correlation was shown by Mitsuhiro Nakamura in a limited range of target speeds. ${ }^{13)}$

Further research of causes of artifacts and interrelationships among them is required in order to understand the limitations of current 4D CT technology and to achieve better imaging of moving organs. Therefore, we designed and conducted a series of experiments to explore the partial volume effect (PVE), PPE, and MMimph in 4D CT scans of a target with regular motion.

\section{MATERIALS AND METHODS}

\section{Phantom}

Two types of phantoms, a thoracic phantom and three cylindrical phantoms, were used in our experiments. An irregularly shaped target object of approximately $15 \mathrm{cc}$ was inserted into the lung section of the thoracic phantom. The phantom was made to move in the superior - inferior (SI) direction with 1 $\mathrm{cm} / 2 \mathrm{~cm}$ peak amplitude and a period of $4 \mathrm{sec} / 6 \mathrm{sec}$ in a sinusoidal pattern.

Cylindrical phantoms had a diameter of $2 \mathrm{~cm}$ and different heights; No.1 had a height of $0.5 \mathrm{~cm}$ and No. 2 was $10 \mathrm{~cm}$. The shorter height of No. 1 was specially chosen to test MMimph. The $10 \mathrm{~cm}$ height of No. 2 was used to remove the
PVE by scanning an infinitely long object relative to the acquisition scan ranges, which were $2 \mathrm{~cm}$ and $6 \mathrm{~cm}$ in the experiments.

The cylinders were positioned parallel to each other, and their centers were aligned (Fig. 1) on a moving table, similar to the thoracic phantom. To limit the motion of phantom No. 1 within one scanning bed, the motion peak amplitude in the SI direction was chosen to be $0.5 \mathrm{~cm}$ (peak-to-peak displacement $=1 \mathrm{~cm}$ ). To test the impact of gantry rotation speed relative to target speed, which is relevant to PPE on image quality, we selected motion periods of $2 \mathrm{sec}$ and $6 \mathrm{sec}$.

\section{Data acquisition}

All CT data were acquired by a 16-slice CT scanner with an $80 \mathrm{~cm}$ bore size (LightSpeed RT16: General Electric Healthcare, Waukesha, WI). First, the static scan data were acquired as references, and then the respiratory-gated cine CT scan was performed. The respiratory phase was detected using a realtime position management (RPM) system (Varian, Palo Alto, CA). During scanning, $40 \mathrm{~cm}$ of display field of view (DFOV) which is generally used a patient's torso scan and a standard reconstruction algorithm was used. Slice thicknesses of 2.5 and $1.25 \mathrm{~mm}$ were used for static data, and a slice thickness of 2.5 $\mathrm{mm}$ was used for gated cine data.

For the thoracic phantom scanning, clinical scan parameters were used for the moving phantom (120 $\mathrm{kVp}$ and $250 \mathrm{~mA})$.

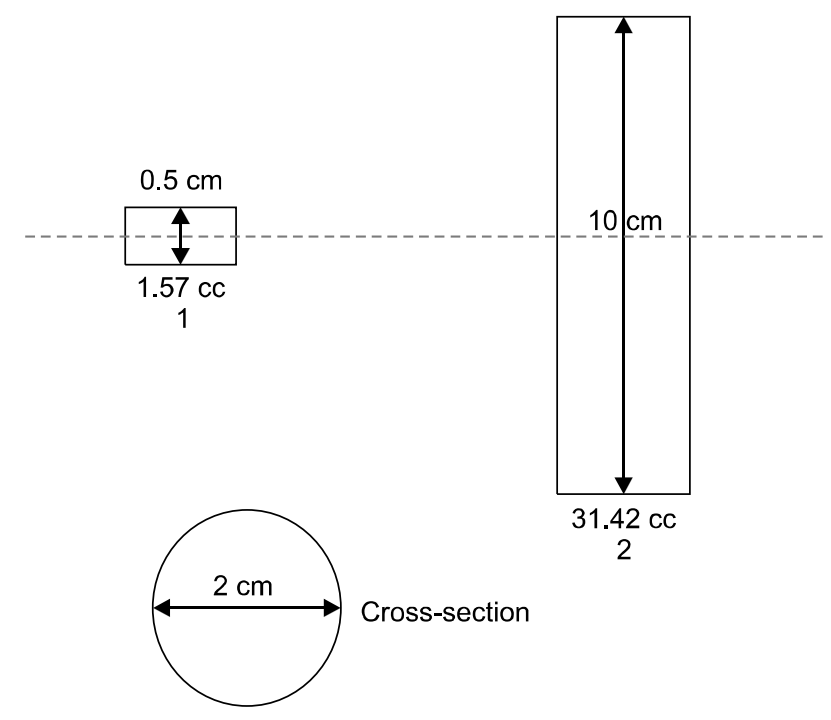

Fig. 1. Cylindrical phantoms and their scan positions. 
The scan range encompassed the targeted region, and two gantry speeds, $0.5 \mathrm{sec} /$ rotation and $0.8 \mathrm{sec} /$ rotation, were used.

In order to investigate the effect of MMimph on image quality, the thoracic phantom in motion was scanned twice using the following motion parameters: $1 \mathrm{~A} 4 \mathrm{P}(1 \mathrm{~cm}$ peak amplitude and $4 \mathrm{sec}$ period), 1A6P (1 $\mathrm{cm}$ peak amplitude and $6 \mathrm{sec}$ period), 2A4P ( $2 \mathrm{~cm}$ peak amplitude and $4 \mathrm{sec}$ period), and 2A6P (2 $\mathrm{cm}$ amplitude and $6 \mathrm{sec}$ period).

In the first scan, the beam projection was automatically started at each bed, as in normal practice. In the second scan, beam projection was manually started when the phantom arrived at the identical respiratory phase with that of the previous bed. The projection starting time at each bed was synchronized with the respiratory signal; the beam projection was not initiated until the RPM signal reached a specific phase. In the third scan, beam projection was manually started at a phase that was quite different from that of the previous bed in order to maximize the MMimph in the images.

In the cylindrical phantom experiments, non-clinical scanning parameters, $140 \mathrm{kVp}, 500 \mathrm{~mA}$ and $0.5 \mathrm{sec} /$ rotation of the gantry, were used for better image quality. Two sets of scanning measurements were conducted. The first set was a one-bed scan with a scan range of $2 \mathrm{~cm}$ because this eliminated the MMimph by encompassing the No. 1 phantom within one bed. For the No. 2 phantom, only a part of the phantom was scanned. In the second set, images were obtained by a three-bed scan with a range of $6 \mathrm{~cm}$ achieved by shifting the scan range so that the motion range of the No. 1 phantom was within two bed widths, while the motion range of the No. 2 phantom was not influenced by the scan range. All scans were started automatically.

The cine interval was assigned as the ratio of the number of phases, which was tententen, to the cyclic period. The 4D CT data were separately reconstructed into ten phases according to the tagged respiratory phase signal in the Advantage 4D software (General Electric Healthcare, Waukesha, WI). To account for actual phase velocities in the analysis, the RPM data at each of the sorted data points were recorded.

\section{Target volume definition and motion velocity cal- culation}

The target volume was determined using Pinnacle3 (Philips
Healthcare, Andover, MA). One expert contoured the targets, and Pinnacle 3 automatically calculated the target volumes. To maintain consistency, the window level and width were fixed at 1601 and 300, respectively. For cylindrical phantoms, both static images and the 4D CT images were analyzed, and the measured volume to true volume ratio (MsTrueV) was calculated as a measure of imaging accuracy. The true volumes of the cylindrical phantom were calculated, and the true target volume in the thoracic phantom was measured.

The velocity of the object at each phase and bed position was computed following the equation of Mitsuhiro Nakamura, ${ }^{11)}$ as shown below. Although actual velocities at the same phase in different bed positions might be different, the average velocities in all beds were computed as follows:

$\mathrm{V}_{\mathrm{j}}(\mathrm{p})=\frac{-2 \pi A}{T} \sin \left[\frac{2 \pi}{100} p h\right]$

$\operatorname{ABS}\left(\mathrm{V}_{\mathrm{j}}(\mathrm{p})\right)=\left|\mathrm{V}_{\mathrm{j}}(\mathrm{p})\right|$

$\mathrm{V}(\mathrm{p})=\sum_{\mathrm{j}=\text { all beds }} \operatorname{ABS}\left(\mathrm{V}_{\mathrm{j}}(\mathrm{p})\right) /$ No. of beds

In these equations, $\mathrm{p}$ is the nominal percentage phase and varies from $0 \%$ to $90 \%$, and ph is the percent phase actually detected by RPM, which is different from the nominal phase within the allowed error range. $V_{j}(p)$ is the velocity of the phantom at the $\mathrm{p}^{\text {th }}$ phase in the $\mathrm{j}^{\text {th }}$ bed, $\mathrm{A}$ is amplitude, $\operatorname{ABS}\left(\mathrm{V}_{j}(\mathrm{p})\right)$ is the absolute velocity of $\mathrm{V}_{j}(\mathrm{p})$, and $\mathrm{V}(\mathrm{p})$ is the average of the averaged $\mathrm{ABS}(\mathrm{Vj}(\mathrm{p}))$ in all of the beds (Fig. 2).

MsTrueV was plotted according to $\mathrm{V}(\mathrm{p})$, and the linear correlation between MsTrueV and velocity V(p) was statistically tested.

In order to assess MMimph, the difference in the initial velocities at the starting projection at each bed was calculated as follows:

$$
\begin{aligned}
\mathrm{V}^{\text {difference }(\%)}= & \left\{\mathrm{ABS}\left(\mathrm{V}_{\mathrm{j}-1}\left(\mathrm{p} 0^{\prime}\right)\right)-\mathrm{ABS}\left(\mathrm{V}_{\mathrm{j}}(\mathrm{p} 0)\right) / \mathrm{ABS}\left(\mathrm{V}_{\mathrm{j}-1}\left(\mathrm{p} 0^{\prime}\right)\right)\right\} \times 100(\%) \\
& \mathrm{ABS}\left(\mathrm{V}^{\text {difference }(\%)}\right)=\left|\mathrm{V}^{\text {difference }(\%)}\right|
\end{aligned}
$$

where $\mathrm{V}^{\text {difference (\%) }}$ is the percent difference of the absolute value of the initial velocities between adjacent beds, and $V_{j}(p 0)$ and $\mathrm{V}_{\mathrm{j}-1}\left(\mathrm{p} 0^{\prime}\right)$ are the velocities of the initial phases $\left(\mathrm{p} 0 / \mathrm{p}^{\prime}\right)$ in the $\mathrm{j}^{\text {th }}$ and $\left(\mathrm{j}^{\text {th }}-1\right)$ beds, respectively. The initial phase, $\mathrm{p} 0$, at the initiation of gantry rotation of each bed was defined as the percent phase of the first slice of each bed, and $\mathrm{V}^{\text {difference }(\%)}$ 
Heesoon Sheen, et al : Analysis of Acuqisiton Parameters Caused 4D CT Aftifact with Regular Motion

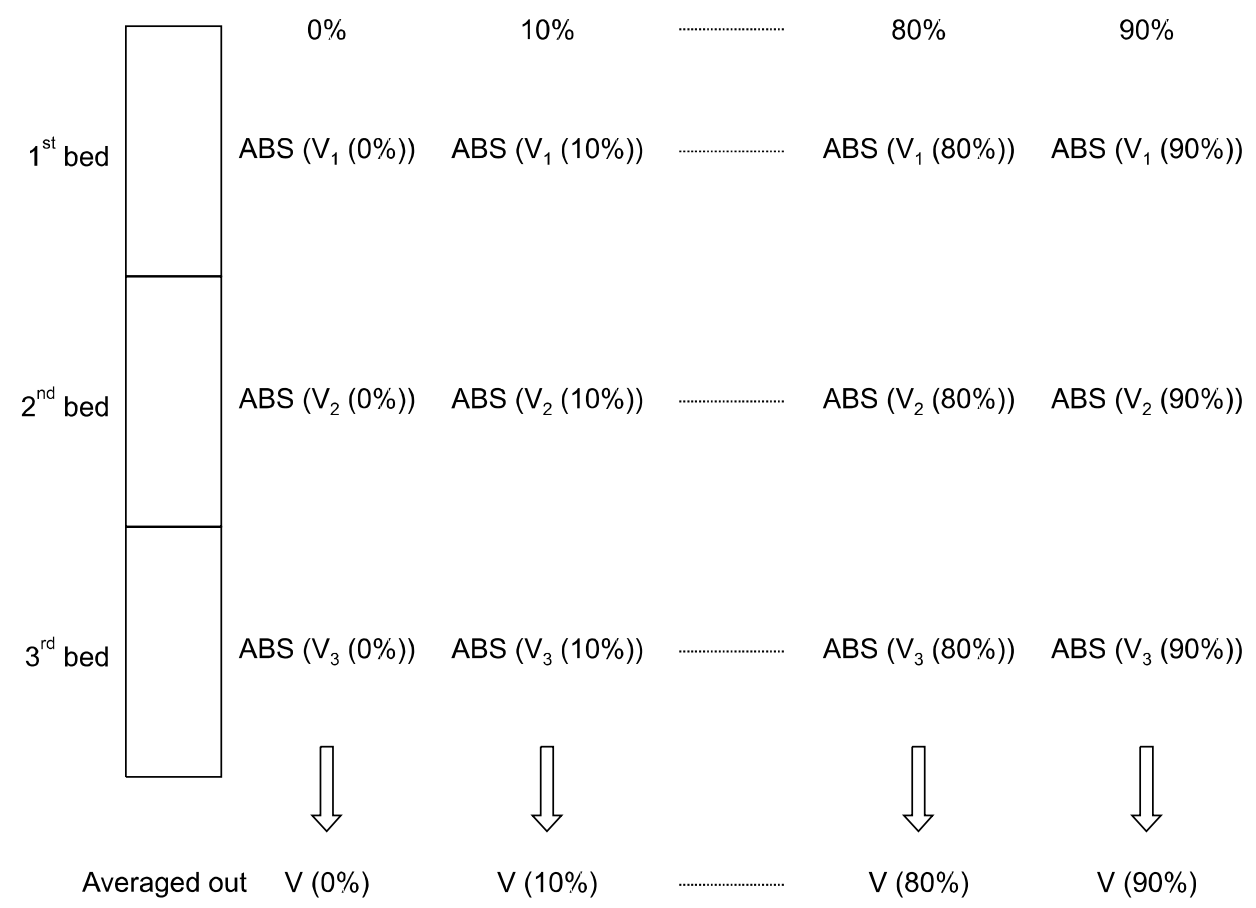

Fig. 2. The method of computing the absolute velocity at each bed.

was computed only for the center bed which was the main part of the whole lesion volume. The relationship among MsTrueV, its velocity, and $\mathrm{ABS}\left(\mathrm{V}^{\text {difference }}{ }^{(\%)}\right)$ was analyzed.

\section{RESULTS}

\section{Thoracic phantom}

In Table 1 and Fig. 4 the velocities and MsTrueV values obtained from the various motions of the thoracic phantom are summarized. The minimum and maximum velocities were 0.15 and $3.03 \mathrm{~cm} / \mathrm{sec}$ for $5 \mathrm{sec} /$ rotation, and the corresponding MsTrueV were 1.35 and 1.75 , respectively. For $0.8 \mathrm{sec} /$ rotation, the velocity ranged from 0.23 to $3.08 \mathrm{~cm} / \mathrm{sec}$, and the corresponding MsTrueV ranged from 1.53 to 2.12. As shown in Table 2, when scanning was automatically performed, $\mathrm{ABS}\left(\mathrm{V}^{\text {difference (\%) }}\right)$ was $3.27 \% \sim 53.57 \%$. The correlation between MsTrueV and velocity ranged from 0.75 to 0.9 . Automatic initiation could not control the initial phase at each of the beds. When the projection was manually started, the velocity differences ranged from $0 \%$ to $200 \%$, and the corresponding correlation coefficients were $0.39 \sim 0.93$. In the second scanning, in which data acquisition was synchronized with

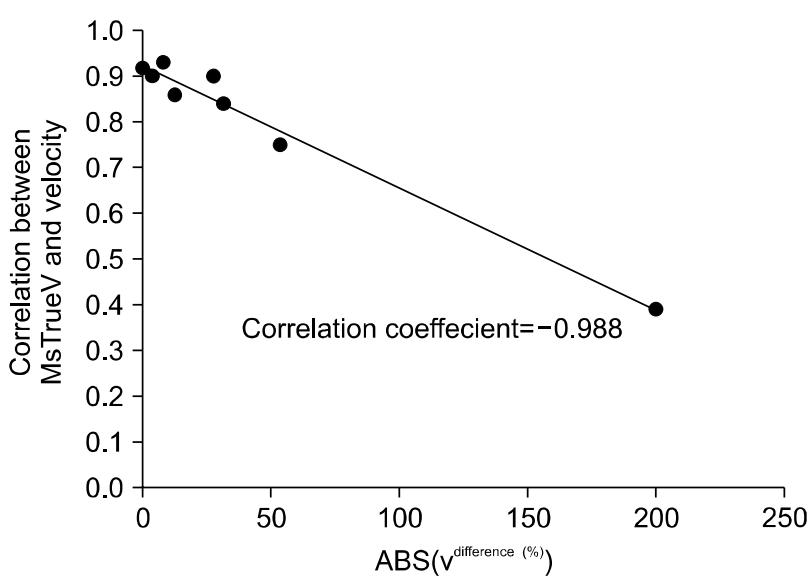

Fig. 3. The correlation between $\mathrm{ABS}\left(\mathrm{V}^{\text {difference }(\%)}\right)$ and the correlation between MsTrueV and velocity in the moving thoracic phantom.

the respiratory phase at the initial projection, the difference was less than $12.42 \%$, and the correlation was greater than 0.86. In the third scanning, $200 \%$ of the difference of initial velocity resulted in a poor correlation of 0.39 . We observed a linear dependency of the correlation between the velocity and the MsTrueV on the ABS( $\left.\mathrm{V}^{\text {difference (\%) }}\right)$ (coefficient - 0.99), as shown in Fig. 3 and Table 2. 
Table 1. Velocity and MsTrueV values obtained from 1A4P (amplitude $1 \mathrm{~cm}$, period $4 \mathrm{sec}$ ), 1A6P, 2A4P, and 2A6P using the thoracic phantom. The scan was automatically started, and the image slice thickness was $2.5 \mathrm{~mm}$.

\begin{tabular}{|c|c|c|c|c|c|}
\hline \multirow{2}{*}{ Motion type } & \multirow{2}{*}{$\begin{array}{c}\text { Gantry rotation time } \\
(\mathrm{sec} / \text { rotation })\end{array}$} & \multicolumn{2}{|c|}{ Velocity (cm/sec) } & \multicolumn{2}{|c|}{ MsTrueV } \\
\hline & & Minimum & Maximum & Minimum & Maximum \\
\hline $1 \mathrm{~A} 4 \mathrm{P}$ & 0.5 & 0.27 & 1.49 & 1.35 & 1.68 \\
\hline $1 \mathrm{~A} 4 \mathrm{P}$ & 0.8 & 0.23 & 1.53 & 1.53 & 1.88 \\
\hline $1 \mathrm{~A} 6 \mathrm{P}$ & 0.5 & 0.15 & 1.02 & 1.31 & 1.58 \\
\hline $1 \mathrm{~A} 6 \mathrm{P}$ & 0.8 & 0.23 & 1.55 & 1.32 & 1.62 \\
\hline $2 \mathrm{~A} 4 \mathrm{P}$ & 0.5 & 0.53 & 3.03 & 1.26 & 1.75 \\
\hline $2 \mathrm{~A} 4 \mathrm{P}$ & 0.8 & 0.52 & 3.08 & 1.38 & 2.12 \\
\hline $2 \mathrm{~A} 6 \mathrm{P}$ & 0.5 & 0.26 & 2.03 & 1.34 & 1.98 \\
\hline $2 \mathrm{~A} 6 \mathrm{P}$ & 0.8 & 0.39 & 1.53 & 1.35 & 1.85 \\
\hline
\end{tabular}

MsTrueV: Measured target volume to true volume ratio.
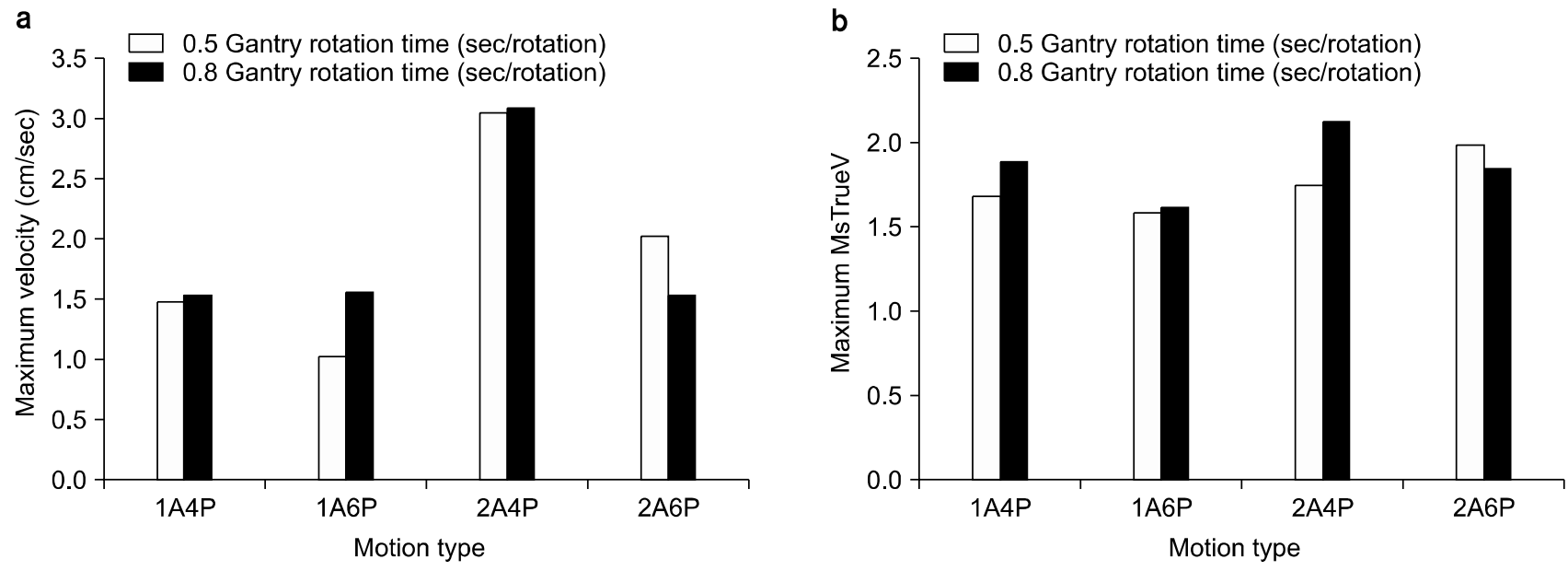

Fig. 4. Velocity and MsTrueV values obtained from 1A4P (amplitude $1 \mathrm{~cm}$, period $4 \mathrm{sec}$ ), 1A6P, 2A4P, and 2A6P using the thoracic phantom. The scan was automatically started, and the image slice thickness was $2.5 \mathrm{~mm}$.

\section{Cylindrical phantom}

The MsTrueV values of static phantoms ranged from 1.20 to 2.03 (Table 3). Table 4 shows the relationship between the velocity and MsTrueV. MsTrueV for No.1 was much larger than the static cases, while the value of No. 2 was similar to the static case. When the No.1 $(1.57 \mathrm{cc})$ phantom was moving with an amplitude of $0.5 \mathrm{~cm}$ and a period of $6 \mathrm{sec}(0.5 \mathrm{~A} 6 \mathrm{P})$, the linear correlation coefficient between MsTrueV and its velocity was 0.89 and 0.88 in one- and three-bed scans, respectively. For the $2 \mathrm{sec}$ period $(0.5 \mathrm{~A} 2 \mathrm{P})$, the correlation was very low $(-0.04)$ in three-bed scans. For the No. 2 phantom in
0.5A6P motion, the correlation was 0.57 and 0.13 in the oneand three-bed scans, respectively. For $0.5 \mathrm{~A} 2 \mathrm{P}$, the correlation measured in three-bed images was -0.32 .

\section{DISCUSSION}

\section{Static phantom tests}

It is known that the volume representation of a static phantom is mainly affected by PVE. The manually defined object volumes for static cylindrical phantoms were at least 1.20 times larger than the real volume. According to Rietzel's research $^{5)}$ the PVE is more pronounced for a small object and 
results in over-estimation in volume representation

Two cylindrical phantoms have the same cross-sectional area,

Table 2. MMimph and MsTrueV: MsTrueV for $2 \mathrm{~cm}$ amplitude with $4 \mathrm{sec}$ and $6 \mathrm{sec}$ period motion (2A4P and $2 \mathrm{~A} 6 \mathrm{P}), 1 \mathrm{~A} 4 \mathrm{P}$, and $1 \mathrm{~A} 6 \mathrm{P}$. Gantry rotations were $0.8 \mathrm{sec}$ per rotation. Images slice thickness was $2.5 \mathrm{~mm}$. MMimph: $\mathrm{V}^{\mathrm{j}}(\mathrm{p})$ is velocity of $p \%$ phase in the jth bed ( $A$ : amplitude, $p: \%$ phase). $A B S\left(V^{j}(p)\right)=\mid\left(V^{j}(p) \mid, V^{\text {difference }(\%)}=\left\{A B S\left(V^{j-1}\left(p^{\prime}\right)-A B S\right.\right.\right.$ $\left(\mathrm{V}^{j}(\mathrm{p})\right\}^{*} 100(\%) / \operatorname{ABS}\left(\mathrm{V}^{\mathrm{j}-1}(\mathrm{p})\right)$.

\begin{tabular}{cclcc}
\hline \hline $\begin{array}{c}\text { Motion } \\
\text { type }\end{array}$ & $\begin{array}{c}\text { Gantry } \\
\text { rotation time } \\
(\mathrm{sec} / \text { rotation })\end{array}$ & $\begin{array}{c}\text { Scan } \\
\text { initiation } \\
\text { method }\end{array}$ & $\begin{array}{c}\text { ABS } \\
\left(\mathrm{V}^{\text {difference }}{ }^{(\%)}\right)\end{array}$ & $\begin{array}{c}\text { Correlation } \\
\text { between } \\
\text { MsTrueV } \\
\text { and velocity }\end{array}$ \\
\hline 1A4P & 0.8 & Auto & 53.57 & 0.75 \\
1A4P & 0.8 & Manual & 12.42 & 0.86 \\
1A6P & 0.8 & Auto & 50 & 0.84 \\
1A6P & 0.8 & Manual & 200 & 0.39 \\
2A4P & 0.8 & Auto & 27.61 & 0.9 \\
2A4P & 0.8 & Manual & 0 & 0.92 \\
2A6P & 0.8 & Auto & 3.27 & 0.9 \\
2A6P & 0.8 & Manual & 8.11 & 0.93 \\
\hline \hline
\end{tabular}

MsTrueV: measured target volume to true volume ratio. $\operatorname{ABS}\left(\mathrm{V}_{j}(\mathrm{p})\right)=\mid\left(\mathrm{V}_{\mathrm{j}}(\mathrm{p}) \mid: \mathrm{V}_{\mathrm{j}}(\mathrm{p})\right.$ is velocity of $\mathrm{p} \%$ phase in $\mathrm{j}^{\text {th }}$ bed $(\mathrm{A}$ : Amplitude, $\mathrm{p}: \%$ phase).

$\mathrm{V}^{\text {difference }}{ }^{(\%)}=\left\{\mathrm{ABS}\left(\mathrm{V}_{\mathrm{j}-1}\left(\mathrm{p}^{\prime}\right)-\mathrm{ABS}\left(\mathrm{V}_{\mathrm{j}}(\mathrm{p})\right\}{ }^{*} 100(\%) / \mathrm{ABS}\left(\mathrm{V}_{\mathrm{j}-1}(\mathrm{p})\right)\right.\right.$. so the PVE in the axial (cranio-caudal) direction predominates over the cross-sectional direction. This explanation is supported by the observation of reduced PVE in thinner slice $(1.25 \mathrm{~mm})$ images, while the PVE for No. 2 was not much different in the images scanned at $1.25 \mathrm{~mm}$ and $2.5 \mathrm{~mm}$ (Table 3). The No. 2 phantom (radius $2 \mathrm{~cm}$ and height $10 \mathrm{~cm}$ ) had nearly the same MsTrueV in the images scanned at $1.25 \mathrm{~mm}$ and 2.5 $\mathrm{mm}$ since PVE was relatively small for the large volume.

\section{Moving phantom tests}

The effects of PVE, PPE, and MMimph on 4D CT motion artifacts were clarified through our tests.

In the thoracic phantom study, we confirmed that the measured volumes in low velocity phases, such as $0 \%, 50 \%$, and $90 \%$, were closer to the true volume, while the volume was overestimated in the high-speed phases, as previous studies have reported (Fig. 4). ${ }^{11)}$ The results obtained from the moving phantom studies, which examined the relationship between PPE and gantry speed, showed that the detected velocity of phantom motion was similar but the measured volumes were different for two different gantry rotation times. MsTrueV of the $0.5 \mathrm{sec}$ gantry rotation time was less than that of the 0.8

Table 3. Acquisition parameters, volume, and MsTrueV values for the static cylindrical phantom.

\begin{tabular}{cccccc}
\hline \hline No. & Scan mode & $\begin{array}{c}\text { Gantry rotation time } \\
\text { (sec/rotation) }\end{array}$ & Slice thickness (mm) & Measured volume (cc) & MsTrueV \\
\hline \multirow{2}{*}{1} & Axial & 0.5 & 1.25 & 2.48 & 1.58 \\
& Axial & 0.5 & 2.5 & 3.19 & 2.03 \\
2 & Axial & 0.5 & 1.25 & 23.13 & 1.29 \\
& Axial & 0.5 & 2.5 & 21.67 & 1.2 \\
\hline \hline
\end{tabular}

MsTrueV: measured target volume to true volume ratio.

$\operatorname{ABS}(\operatorname{Vj}(\mathrm{p}))=\mid\left(\mathrm{V}_{\mathrm{j}}(\mathrm{p}) \mid: \mathrm{V}_{\mathrm{j}}(\mathrm{p})\right.$ is velocity of $\mathrm{p} \%$ phase in $\mathrm{j}^{\text {th }}$ bed (A: Amplitude, $\mathrm{p}: \%$ phase).

$\mathrm{V}^{\text {difference }(\%)}=\left\{\operatorname{ABS}\left(\mathrm{V}_{\mathrm{j}-1}\left(\mathrm{p}^{\prime}\right)-\mathrm{ABS}\left(\mathrm{V}_{\mathrm{j}}(\mathrm{p})\right\}^{*} 100(\%) / \mathrm{ABS}\left(\mathrm{V}_{\mathrm{j}-1}(\mathrm{p})\right)\right.\right.$.

Table 4. MsTrueV values for cylindrical phantoms moving with $0.5 \mathrm{~cm}$ amplitude and a 6 sec cycle.

\begin{tabular}{|c|c|c|c|c|c|c|c|}
\hline \multirow{2}{*}{ Motion type } & \multirow{2}{*}{$\begin{array}{l}\text { Gantry } \\
\text { rotation time } \\
\text { (sec/rotation) }\end{array}$} & \multirow{2}{*}{ Scan method } & \multirow{2}{*}{ No. of beds } & \multirow{2}{*}{ No. of phantoms - } & \multicolumn{2}{|c|}{ MsTrueV } & \multirow{2}{*}{$\begin{array}{l}\text { Correlation between } \\
\text { MsTrueV and velocity }\end{array}$} \\
\hline & & & & & Min & Max & \\
\hline \multirow[t]{2}{*}{$0.5 \mathrm{~A} 6 \mathrm{P}$} & 0.5 & Auto & 1 & 1 & 1.62 & 2.15 & 0.89 \\
\hline & & & & 2 & 1.22 & 1.26 & 0.57 \\
\hline \multirow[t]{2}{*}{$0.5 \mathrm{~A} 6 \mathrm{P}$} & 0.5 & Auto & 3 & 1 & 1.74 & 2.22 & 0.88 \\
\hline & & & & 2 & 1.19 & 1.21 & 0.13 \\
\hline
\end{tabular}

MsTrueV: measured target volume to true volume ratio. 
sec gantry rotation time in three sets among four sets of motion (Table 1, Fig. 4). This indicated that a shorter gantry rotation period could provide more precise volume estimation. In the analysis of projections of phantom motion $(6 \mathrm{sec})$, the projections acquired during the whole cyclic period of phantom motion were either sufficient or insufficient depending on the relative gantry rotation time compared to the motion period. A shorter gantry rotation time than phantom motion period provided sufficient data sampling, while longer gantry rotation time than phantom motion period did not. Therefore, the use of gantry rotation that is faster than the motion period could eliminate PPE.

MMimph affects the correlation between MsTrueV and velocity. We found that smaller $\mathrm{ABS}\left(\mathrm{V}^{\text {difference }}{ }^{(\%)}\right)$ led to a better correlation between MsTrueV and velocity (Table 2). Fig. 3 demonstrates that an increase in MMimph $\left(\mathrm{V}^{\text {difference (\%) }}\right)$ reduced the correlation between MsTrueV and velocity. This phe- nomenon is explained in Fig. 5, which plots the calculated velocity vs. the percentage phase actually detected by RPM at each bed.

As shown in plot, the initial projection angle of the phantom led to deviation of the actual phases of the same nominal phase, which was measured by $\mathrm{ABS}\left(\mathrm{V}^{\text {difference (\%) }}\right)$. For example (Fig. 6), for $40 \%$ of phases, the phases that were actually detected in the first, second, and third beds were $41 \%, 35 \%$, and $37 \%$, respectively. This observed deviation resulted in the loss of correlation between the volume and velocity. From various motions with different velocities, our data show that the correlation between the velocity and the MsTrueV was better when $\mathrm{ABS}\left(\mathrm{V}^{\text {difference (\%) }}\right)$ was smaller. The correlation was larger than 0.9 when $\mathrm{ABS}\left(\mathrm{V}^{\text {difference }(\%)}\right)$ was less than $10 \%$, while the coefficient was reduced to 0.39 when $\mathrm{ABS}\left(\mathrm{V}^{\text {difference }(\%)}\right)$ was $200 \%$.

For the cylindrical phantom studies, a $0.5 \mathrm{sec}$ gantry rota-
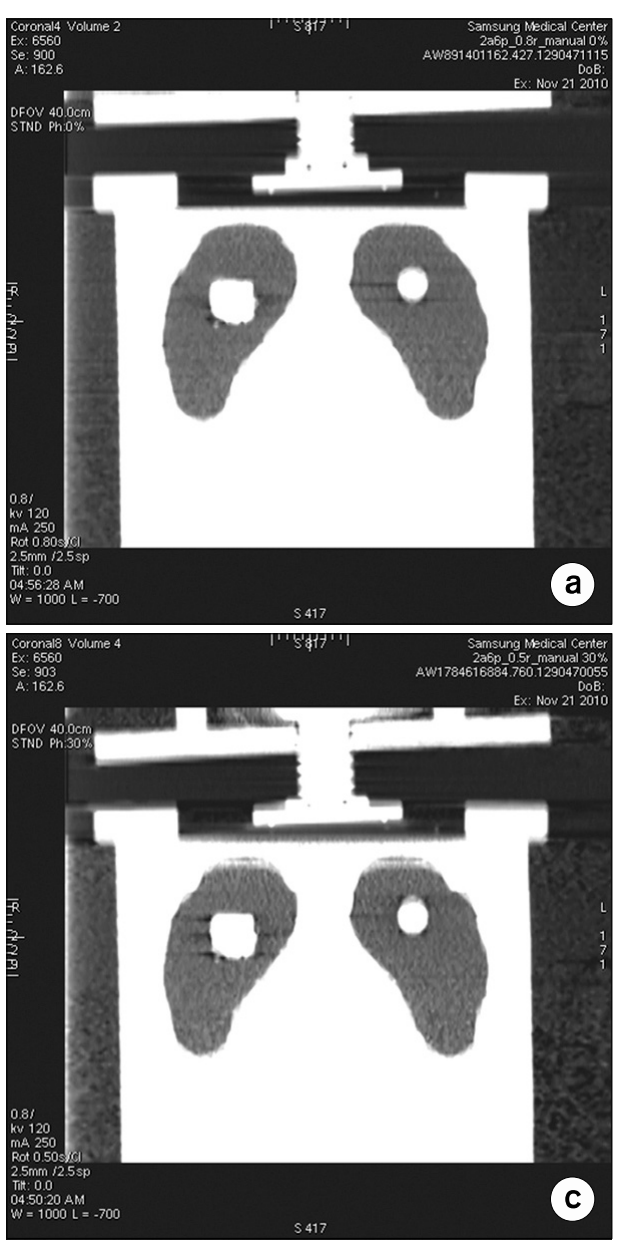
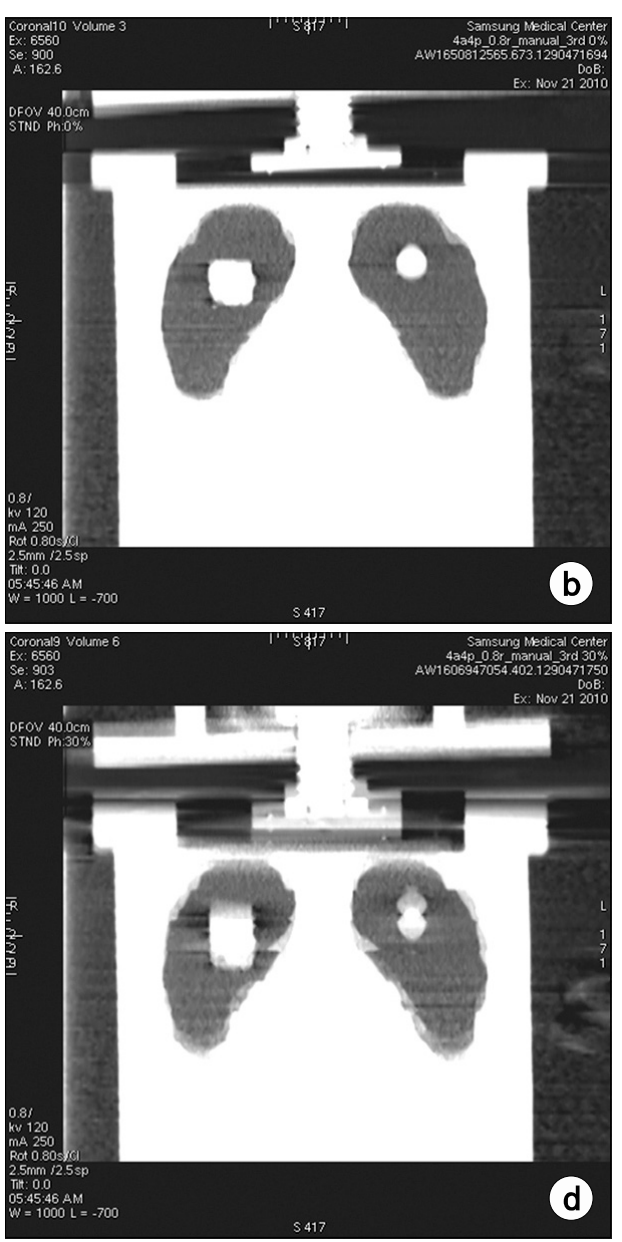

$-249-$
Fig. 5. $4 \mathrm{D}$ CT motion artifacts in 1A6P (amplitude $1 \mathrm{~cm}$, period 6 sec) and 2A4P with 0.8 sec gantry rotation time: a) $0 \%$ of respiratory phase for $1 \mathrm{~A} 6 \mathrm{P}, \mathrm{b}) 30 \%$ of respiratory phase for $1 \mathrm{~A} 6 \mathrm{P}, \mathrm{c})$ $0 \%$ of respiratory phase for $2 \mathrm{~A} 4 \mathrm{P}$, and d) $30 \%$ of respiratory phase for $2 \mathrm{~A} 4 \mathrm{P}$. 


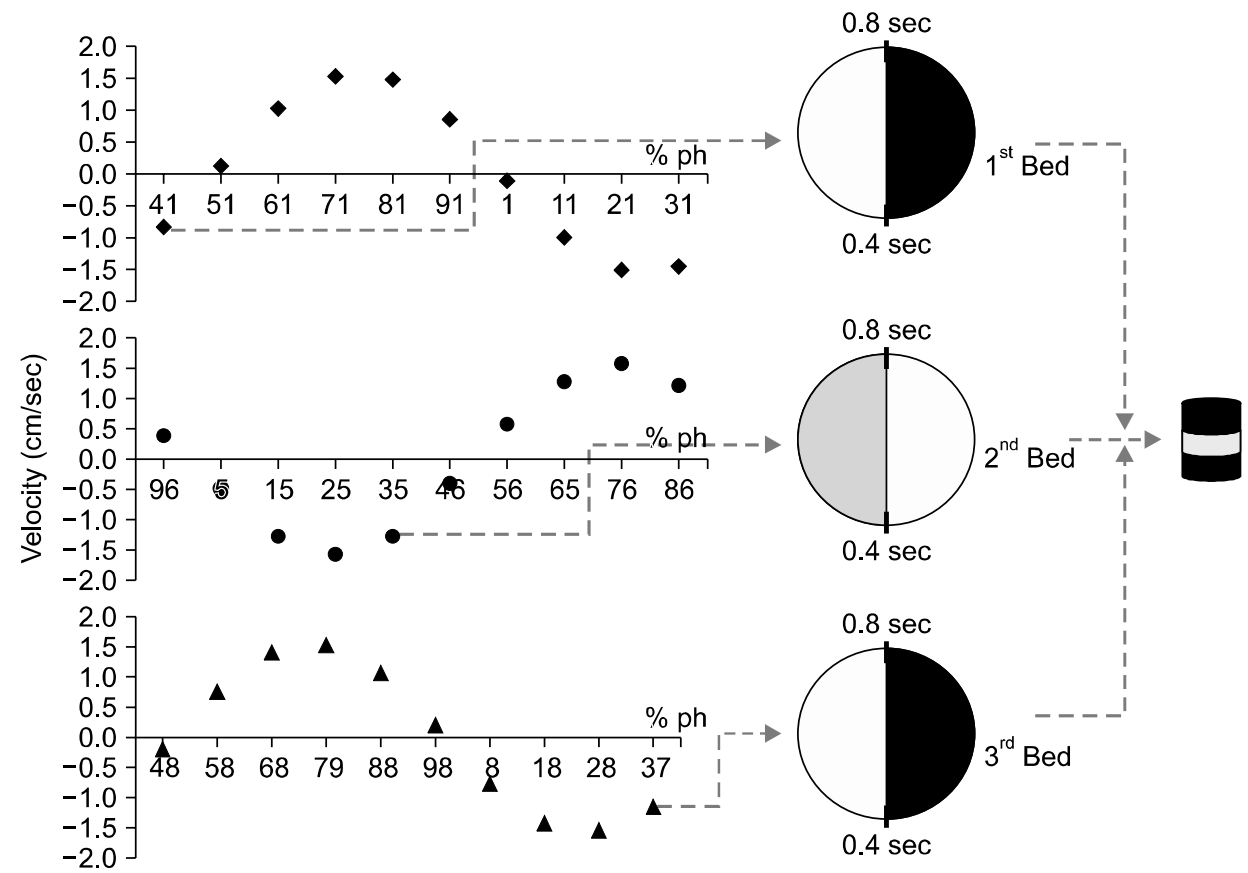

Fig. 6. Calculated velocity vs. percentage phase actually detected by RPM at each bed. The first phase at the X-axis indicates the phase at gantry angle 0 . Phantom motion had an amplitude of $0.5 \mathrm{~cm}$ and a motion period 4 sec. 1A4P: gantry rotation time 0.8 sec, interleaved between images for $0.4 \mathrm{sec}$ in three beds. In the first bed, the initial phase at a gantry angle of 0 degrees was $40 \%$ (actual 41\%), while the initial phases changed to $0 \%$ and $50 \%$ in the second and third beds, respectively. The different initial projection angles of the phantom, which caused large $\mathrm{ABS}\left(\mathrm{V}^{\text {difference }}{ }^{(\%)}\right)$, resulted in different velocities at the same nominal phase percent range among beds, which were $41 \%, 35 \%$, and $37 \%$ in the first, second, and third beds, respectively, for the nominal $40 \%$ phase.

Table 5. Computed velocity differences at the starting projection for each bed and MsTrueV values for the cylindrical phantoms with $0.5 \mathrm{~cm}$ amplitude and $6 \mathrm{sec}$ or $2 \mathrm{sec}$ of motion for three-bed scanning.

\begin{tabular}{cccccc}
\hline \hline Motion type & $\begin{array}{c}\text { Gantry rotation time } \\
(\mathrm{sec} / \text { rotation })\end{array}$ & $\begin{array}{c}\text { Scan initiation } \\
\text { method }\end{array}$ & $\mathrm{ABS}\left(\mathrm{V}^{\text {difference (\%) })}\right.$ & No. of phantoms $\begin{array}{c}\text { Correlation between the velocity } \\
\text { and } \mathrm{MsTrueV}\end{array}$ \\
\hline 0.5A6P & 0.5 & Auto & 8.71 & 1 & 0.88 \\
$0.5 \mathrm{~A} 2 \mathrm{P}$ & \multirow{2}{*}{0.5} & Auto & 368.78 & 2 & 0.13 \\
& & & 2 & -0.04 & -0.32 \\
\hline
\end{tabular}

MsTrueV: Measured target volume to true volume ratio.

$\operatorname{ABS}\left(V_{j}(p)\right)=\mid\left(V_{j}(p) \mid: V_{j}(p)\right.$ is velocity of $p \%$ phase in $j^{\text {th }}$ bed (A: Amplitude, $p$ : \% phase).

$\mathrm{V}^{\text {difference }(\%)}=\left\{\operatorname{ABS}\left(\mathrm{V}_{\mathrm{j}-1}\left(\mathrm{p}^{\prime}\right)-\mathrm{ABS}\left(\mathrm{V}_{\mathrm{j}}(\mathrm{p})\right\}^{*} 100(\%) / \operatorname{ABS}\left(\mathrm{V}_{\mathrm{j}-1}(\mathrm{p})\right)\right.\right.$.

tion time was used to eliminate PPE for the $6 \mathrm{sec}$ period of motion. In one-bed images, the artifact due to MMimph was not seen, and it is believed that No. 1 was moved only inside one bed. No. 2 simulated an infinite length object to mimic the minimal motion effect. The correlation between MsTrueV and velocity was high for the No. 1 phantom (Table 4) under the condition of no PPE and minimal MMimph. The results demonstrated that PVE artifact increased with velocity. The results obtained from $0.5 \mathrm{~A} 2 \mathrm{P}$ studies (Table 5) showed that MMimph was the main factor reducing the correlation between MsTrueV and velocity ( $-0.04, \operatorname{ABS}\left(\mathrm{V}^{\text {difference }(\%)}\right)$ : $\left.368.78 \%\right)$, although the correlation was supposed to exist due to PPE at $2 \mathrm{sec}$ of phantom motion. In the case of the No. 2 studies, in which the resultant images were rarely affected by PPE or 
PPV, MsTrueV for various motions was nearly similar to that for the static state.

The work presented here suggests that PVE, PPE, and MMimph all contribute to artifacts in 4D CT.

\section{CONCLUSION}

The resulting 4D CT images showed significant shape distortions on the edges of objects under high velocity. PVE existed in all of the data. The artifacts were more evident on the smaller objects. Thinner slice thickness provided more accurate volume estimation for smaller objects.

Small target velocity reduces the PVE, and faster gantry rotation time decreases PPE, which results in more accurate volume description. We found that MMimph was the main parameter reducing the correlation between MsTrueV and velocity. Without reducing the MMimph, controlling target velocity and gantry rotation will not guarantee accurate image presentation given the scope of current 4D CT technology. A respiratory phase synchronizes with the gantry starting angle and then it can potentially improve the accuracy of 4D CT imaging.

\section{REFERENCES}

1. Lecchi M, Fossati P, Elisei F, Orecchia R, Lucignani $\mathrm{G}$ : Current concepts on imaging in radiotherapy. Eur $\mathrm{J}$ Nucl Med Mol Imaging 35(4): 821-837 (2008)

2. Rietzel E, Pan T, Chen GT: Four-dimensional computed tomography: image formation and clinical protocol. Med Phys 32(4):874-889 (2005)
3. Wong JW, Sharpe MB, Jaffray DA, et al: The use of active breathing control $(A B C)$ to reduce margin for breathing motion. Int J Radiat Oncol Biol Physics 44:911-919 (1999)

4. Hanley J, Debois NM, Mah D, et al: Deep inspiration Breath-hold technique for lung tumors: the potential value of target immobilization and reduced lung density in dose escalation: Int J Radiat Oncol Biol Physics 45:603-611 (1999)

5. Shin EH, Park HC, Han YY, et al: Efficacy of a respiratory training system on the regularity of breathing. J. Korean Soc Ther Radiol 26(3):181-188 (2008)

6. Minohara S, Endo M, Kanai T, Kato H, Tsujii H: Estimating uncertainties of the geometrical range of particle radiotherapy during respiration. Int $\mathrm{J}$ Radiat Oncol Biol Phys 56(1): 121-125 (2003)

7. Wurstbauer K, Deutschmann H, Kopp P, Sedlmayer F: Radiotherapy planning for lung cancer: slow CTs allow the drawing of tighter margins. Radiother Oncol 75(2):165-170 (2005)

8. Lagerwaard FJ, Van Sornsen de Koste JR, NijssenVisser MR, et al: Multiple "slow" CT scans for incorporating lung tumor mobility in radiotherapy planning. Int $\mathrm{J}$ Radiat Oncol Biol Phys 51(4):932-937 (2001)

9. Vedam SS, Keall PJ, Kini VR, Mostafavi H, Shukla HP, Mohan R: Acquiring a four-dimensional computed tomography dataset using an external respiratory signal. Phys Med Biol 48(1):45-62 (2003)

10. Keall PJ: 4-dimensional computed tomography imaging and treatment planning. Semin Radiat Oncol 14(1):81-90 (2004)

11. Keall PJ, Starkschall G, Shukla H, et al: Acquiring $4 D$ thoracic CT scans using a multislice helical method. Phys Med Biol 49(10):2053-2067 (2004)

12. Mori S, Endo M, Asakura H: Improvement in banding artifacts in four-dimensional computed tomography for radiotherapy planning. Phys Med Biol 51(20): 5231-5244 (2006)

13. Nakamura $M$, Narita $Y$, Sawada $A$, et al: Impact of motion velocity on four-dimensional target volumes: a phantom study. Med Phys 36(5):1610-1617 (2009)

14. Pan $\mathrm{T}$ : Comparison of helical and cine acquisitions for $4 \mathrm{D}-\mathrm{CT}$ imaging with multislice CT. Med Phys 32(2):627-634 (2005) 


\section{표적이 규칙적으로 움직일 때 생기는 $4 \mathrm{DCT}$ 영상의 모션 아티팩트(Motion Artifact) 관련된 원인분석}

*성균관대학교 의과대학 생명의공학협동과정, ${ }^{\dagger}$ 지이 의료기기(한국지사), ${ }^{\ddagger}{ }^{\circ}$ 삼성서울병원 방사선종양학과

$$
\text { 신희순 }{ }^{\dagger} \cdot \text { 한영이 }{ }^{\dagger} \cdot \text { 신은혁 }{ }^{\dagger}
$$

본 연구는 표적이 규칙적으로 움직일 때 생기는 4DCT 영상의 모션 아티팩트(motion artifact) 관련된 원인들인 partial volume effect (PVE), partial projection effect (PPE), 각각의 프레임의 시작점 사이에 불일치(MMimph)의 원인들은 조사 및 분석을 목적으로 했다. 본 기관에서 제작된 흉부팬텀과 아크릴의 두개의 원기둥팬텀(반지름: $2 \mathrm{~cm}$, 길이: $0.5 \mathrm{~cm} /$ 반지름: $2 \mathrm{~cm}$, 길이: $10 \mathrm{~cm}$ )이 규칙적인 움직이는 동안 $\mathrm{CT}$ 을 이용하여 $4 \mathrm{D}$ 영상을 획득했다. 촬영은 자동시작과 각각의 프레임의 시작점을 일치시키기 위해 매뉴얼로 두 가지 방법으로 시작하였다. 첫번째 실험에서는 CT 캔트리 rotation time은 5 초와 8 초가 이용되었다. 각 프레임은 다른 위상으로 시작되었다. 두번째 실험에서는 각 프레임에서 같은 위상으로 시작되게 하기 위해 매뉴얼로 시작했다. 세번째 실험에서는 원기둥팬텀을 2초와 6초를 주기로 움직였다. 각각의 4DCT의 영상에서 표적의 부피를 구했다. 영상으로부터 구한 표적의 부피와 표적의 실제 부피와 비교를 통해 관계를 분석했다. 흉부팬텀 실험에서는 CT의 갠트리 속도가 팬텀의 움직임보다 빠를수록 PVE와 PPE의 영향이 적어짐에 따라 영상에서 얻은 표적 부피는 실제에 근접했다. 각각의 프레임의 시작점이 일치할수록 움직임의 속도와 표적의 부피와 상관관계가 높았다. 원 기둥팬텀에서는 흉부팬텀의 경우와 같이 갠트리 속도가 팬텀의 움직임보다 빠를수록 영상으로부터 구한 표적부피는 실 제 표적부피에 근접했다. 특히 한 slice의 두께가 $2.5 \mathrm{~mm}$ 을 고려 할 때 axial방향의 PVE, PPE, 각각의 프레임의 시작점이 일치가 되는 상태를 시뮬레이션한 길이 $10 \mathrm{~cm}$ 의 원기둥팬텀 실험에서는 영상에서 얻은 표적부피는 표적이 정지되었을 때 영상에서 얻은 부피와 거의 일치했다. 팬텀이 느리게 움직일수록, CT 갠트리의 rotation 시간이 짧을수록 영상에서 얻 은 표적부피는 실제 부피에 근접했다. CT 촬영 시 각각의 프레임의 시작점이 같을수록 표적의 속도와 영상에서 의한 표 적의 부피는 상관관계가 높게 나타났다. CT 갠트리의 rotation 속도를 팬텀의 움직임보다 빠르게 하고, CT 촬영시 각의 프레임의 시작점을 일치시킬수록 실제의 팬텀부피에 근접하리라고 예상된다.

중심단어: 4차원 단층촬영, 부분부피효과, 부분 프로젝션효과, 근접한 배드사이의 초기 위상의 불일치 